\title{
PENGARUH PERILAKU PEMIMPIN, KARAKTERISTIK PRIBADI PEGAWAI, DAN SIFAT PEKERJAAN TERHADAP MOTIVASI PEGAWAI DI DINAS PENDIDIKAN PROVINSI DKI JAKARTA
}

\author{
Arita Marini ${ }^{1}$
}

\begin{abstract}
The staff's motivation is assumed to be significantly affected by their leader's behavior, their personal characteristics, and the nature of their tasks. The causal study reported here aimed to examine the hypothesis. It was conducted in the Educational Office of the DKI Jakarta Province, through a four-month survey, from May 2009 to September 2009, involving 150 staff members who had been randomly selected from the overall 247 staff members. The data of each variable were collected separately by the respondents' filling in a questionnaire. A path technique was employed to analyze the data. The results show positively direct effects of the leader's behavior, the staff's personal characteristics, and the nature of their tasks on their work motivation. A positively direct effect of the leader's behavior was also apparent on the staff's personal characteristics and also the nature of their tasks. But the leaders' behavior showed a positively indirect effect on the staff's motivation through their personal characteristics and the characteristics of their tasks. The findings suggest that variation in the staff's motivation could be minimized if the variables of the leader's behavior, the staff's personal characteristics, and the nature of their tasks are taken into consideration.
\end{abstract}

Keywords: Staff's motivation, leader's behavior, staff's personal characteristics, and the nature of their tasks.

\section{PENDAHULUAN}

Pembentukan Dinas Pendidikan Provinsi DKI Jakarta telah dimulai sejak fungsi pemerintah pusat dalam pendidikan diserahkan kepada otonomi daerah di Jakarta. Dinas Pendidikan Provinsi DKI Jakarta adalah bagian dari pemerintah daerah dalam kegiatan administratif. Kewenangannya telah ditingkatkan untuk banyak hal yang berhubungan dengan pendidikan. Organisasi kegiatan pendidikan dan pengambilan keputusan dari tingkat Dinas sampai tingkat sekolah adalah sumber pendekatan manajemen sumber daya pendidikan untuk mencapai tujuan organisasi Dinas Pendidikan Provinsi DKI Jakarta. Pengorganisasian dengan cara menetapkan hubungan perilaku yang efektif diantara orang-orang sehingga dapat bekerja sama secara efisien dan memperoleh kepuasan pribadi dalam melakukan tugas pilihan dibawah kondisi lingkungan tertentu untuk mencapai beberapa tujuan.

Pada kenyataannya, kualitas pelayanan pendidikan belum efektif yang dapat dilihat dari standar pelayanan minimum yang belum tercapai. Hal ini ditunjukkan dari Penerimaan Peserta Didik Baru (PPDB) yang menggunakan sistem berbasis teknologi informasi masih belum optimal sehingga menyebabkan proses PPDB mengalami keterlambatan pelayanan. Selain itu, kontrol layanan pendidikan gratis untuk siswa SD dan SMP demi memenuhi wajib belajar belum dilaksanakan secara optimal. Lebih jauh lagi, layanan koordinasi bantuan dana BOS (Biaya Operasional Sekolah) belum dilaksanakan secara optimal. Kualitas pelayanan pendidikan yang belum optimal

${ }^{1}$ Dosen PGSD FIP Universitas Negeri Jakarta 
disebabkan diantaranya oleh adanya motivasi pegawai Dinas Pendidikan Provinsi DKI Jakarta yang belum optimal. Data dari kepegawaian menunjukkan bahwa jumlah pegawai yang pendidikan terakhirnya minimal S2 hanya 12,70\%. Sebagian besar pegawai memiliki pendidikan terakhir S1 atau dibawahnya, yaitu 87,30 \%.

\section{Motivasi.}

Motivasi didefinisikan sebagai serangkaian dorongan yang mengarahkan dan mempertahankan perilaku (Hitt, Michael A, 2009: 297). Dorongan ini dapat berasal dari seseorang yang disebut dorongan internal atau dari lingkungan sekelilingnya yang disebut dorongan eksternal. Terdapat 3 kategori variabel dasar yang menentukan motivasi dalam pekerjaan, yaitu (Hitt, 2009:297-298): (1) karakteristik individu yang meliputi kebutuhan, sikap, dan tujuan; (2) karakteristik pekerjaan yang meliputi umpan balik, beban kerja, jenis pekerjaan, dan kebebasan untuk mengambil keputusan dalam pekerjaan; dan (3) karakteristik situasi kerja yang meliputi lingkungan sosial sekitar dan tindakan organisasi. Serupa dengan definisi di atas, motivasi adalah serangkaian dorongan internal dan eksternal yang menyebabkan pegawai memilih sekumpulan tindakan dan melakukan perilaku tertentu (Newstrom, 2007:101). Secara ideal, perilaku ini diarahkan pada pencapaian tujuan organisasi.

Berbeda dengan pendapat sebelumnya, motivasi dapat dideskripsikan sebagai kegigihan suatu tindakan atau kebebasan menentukan suatu tindakan (Mullins, 2005:471). Terdapat 4 karakteristik yang mendasari definisi motivasi, yaitu sebagai berikut (Mullins, 2005:471-472): (1) motivasi dilambangkan sebagai fenomena individu; (2) motivasi dideskripsikan biasanya dengan sengaja; (3) motivasi meliputi berbagai segi; dan (4) tujuan teori motivasi adalah memprediksi perilaku. Serupa dengan definisi sebelumnya, motivasi mewakili dorongan yang menyebabkan seseorang berperilaku yang mengarah pada tujuan (Slocum \& Hellriegel, 2009:126-127). Oleh karena motif pegawai akan mempengaruhi produktivitasnya, salah satu pekerjaan manajemen adalah menyalurkan motivasi pegawai secara efektif menuju pencapaian tujuan organisasi.

Proses motivasi dimulai dari identifikasi kebutuhan seseorang yang merupakan fase 1 (Slocum \& Hellriegel, 2009:128). Kebutuhan adalah defisiensi yang dialami seseorang pada waktu tertentu (fase 1). Kebutuhan dapat menciptakan keadaan tegang dalam individu yang merasa tidak nyaman sehingga mengadakan suatu usaha (fase 2) untuk mengurangi atau menghilangkannya. Motivasi diarahkan pada tujuan (fase 3). Dengan meyakini bahwa perilaku khusus tertentu dapat mengatasi keadaan tegang ini, individu bertindak untuk menguranginya. Mereka menyelesaikan masalah utama agar mudah dilihat dan memperoleh pengaruh dari pemimpin senior (fase 4). Promosi dan kenaikan gaji adalah dua cara dimana organisasi berusaha untuk mempertahankan perilaku yang diinginkan. Keduanya adalah umpan balik kepada pegawai bahwa kebutuhan akan kemajuan dan pengakuan serta perilakunya tepat atau tidak tepat (fase 5). Pada saat pegawai telah menerima penghargaan atau hukuman, maka mereka akan meninjau kembali kebutuhannya (fase 6).

Definisi yang serupa menjelaskan bahwa motivasi adalah serangkaian dorongan yang berenergi yang berasal dari dalam dan luar pegawai, yang memulai usaha sehubungan dengan kerja, dan menentukan arahan, intensitas, dan persistensi (Colquitt, 2009:178-179). Bagian pertama dari definisi motivasi ini mengilustrasikan bahwa motivasi bukanlah berkaitan dengan satu dorongan tetapi serangkaian dorongan yang berbeda. Sama dengan definisi sebelumnya, motivasi adalah apa yang dilakukan oleh pemimpin efektif untuk memberi energi, mengarahkan dan mempertahankan usaha 
pegawainya (Gomez-Mejia \& Balkin, 2002:300-301). Level motivasi yang tinggi akan meningkatkan keberlanjutan untuk menggunakan bakat kearah maksimum, dan sikap ini membuat pegawai lebih bernilai terhadap organisasinya.

Berdasarkan penjelasan yang telah diuraikan, dapat disimpulkan motivasi pegawai adalah serangkaian dorongan internal dan eksternal yang memberikan energi, mengarahkan, dan mempertahankan perilaku pegawai.

\section{Perilaku pemimpin.}

Perilaku pemimpin dapat didefinisikan sebagai apa yang dilakukan pemimpin sehubungan dengan menyelesaikan tugas dan mempertahankan usaha orang-orang melakukan tugas (Gibson et.al, 2006:317). Sesuai dengan definisi sebelumnya, empat tipe utama perilaku pemimpin dalam teori ini adalah sebagai berikut (Mullins, 2005:299): (1) perilaku mengarahkan meliputi membiarkan pegawai mengetahui secara pasti mengenai apa yang diharapkan dari mereka dan memberikan arahan yang spesifik mengenai bagaimana cara menyelesaikan tugas; (2) perilaku mendukung meliputi perilaku yang ramah, mudah memahami, memperhatikan kebutuhan dan kesejahteraan pegawai, serta memperlakukan pegawainya sebagai mitra kerjanya; (3) perilaku partisipatif meliputi adanya konsultasi dengan pegawai dan mengevaluasi pendapat dan usul pegawai sebelum pemimpin mengambil keputusan; dan (4) perilaku berorientasi pada pencapaian meliputi tujuan yang menantang bagi pegawai dan mengharapkan pegawai untuk berkinerja sangat baik.

Berdasarkan definisi di atas, perilaku pemimpin ditentukan oleh dua faktor situasi utama,yaitu (Mullins, 2005:300): (1) karakteristik pribadi bawahan menentukan reaksi terhadap perilaku pemimpin dan sejauh mana perilaku tersebut sebagai sumber kepuasan yang potensial; dan (2) sifat pekerjaan berhubungan dengan sejauh mana pekerjaan itu bersifat rutin dan terstruktur, atau tidak rutin dan tidak terstruktur.

Berbeda dengan definisi sebelumnya, terdapat dua perilaku pemimpin, yaitu perilaku yang terpusat pada pekerjaan dan pegawai (Gibson et.al, 2006:318). Pemimpin yang terpusat pada pekerjaan memfokuskan pada penyelesaian tugas dan menggunakan pengawasan melekat sehingga pegawai melaksanakan tugasnya menggunakan prosedur yang ditentukan. Pemimpin yang terpusat pada pegawai memfokuskan pada orang-orang yang melakukan pekerjaan dan membantu pegawainya dalam memuaskan kebutuhannya dengan cara menciptakan lingkungan kerja yang mendukung.

Model perilaku kepemimpinan memfokuskan pada apa yang sebenarnya dilakukan pemimpin dan bagaimana pemimpin (Slocum \& Hellriegel, 2009:274). Model ini menyatakan bahwa pemimpin yang efektif membantu individu mencapai tujuannya dengan dua cara. Cara pertama, pemimpin membangun hubungan dengan pegawai yang terpusat pada pekerjaan yang memfokuskan pada kualitas dan kuantitas pekerjaan yang diselesaikan. Kedua, pemimpin mempertimbangkan dan mendukung usaha pegawai untuk mencapai tujuan pribadi. Penelitian Program Studi Kepemimpinan Ohio State University ditujukan untuk mengidentifikasi perilaku pemimpin yang penting untuk mencapai tujuan organisasi. Usaha ini menghasilkan dua dimensi utama dari perilaku pemimpin, yaitu: konsiderasi and inisiasi struktur (Slocum \& Hellriegel, 2009:274-276). Konsiderasi adalah sejauh mana pemimpin berhubungan dengan pegawai yang dicirikan oleh saling percaya, komunikasi dua arah, menghormati ide pegawai, dan bersikap empati terhadap perasaan pegawai. Inisiasi struktur adalah sejauh mana pemimpin mendefinisikan dan menentukan peranan pegawai untuk mencapai tujuan dalam daerah tanggung jawabnya. Hersey and Blanchard 
menggunakan studi Ohio State untuk lebih jauh mengembangkan 4 perilaku pemimpin (Gibson, 2006:329): (1) mengatakan dimana pemimpin mendefinisikan peranan yang diperlukan untuk melakukan pekerjaan; (2) menjual dimana pemimpin memberikan pegawainya instruksi terstruktur; (3) berpartisipasi dimana pemimpin dan pegawai bersama-sama memutuskan mengenai cara terbaik melakukan pekerjaan; dan (4) mendelegasikan dimana pemimpin memberikan arahan spesifik.

Berdasarkan uraian diatas dapat disimpulkan bahwa perilaku pemimpin adalah segala sesuatu yang dilakukan pemimpin sehubungan dengan penyelesaian tugas dan mempertahankan usaha orang-orang melakukan tugasnya.

\section{Karakteristik pribadi pegawai.}

Kepribadian individu adalah kombinasi unik antar pola-pola emosi, pikiran, dan perilaku yang mempengaruhi bagaimana seseorang bereaksi dan berinteraksi dengan orang lain (Robbins \& Coulter, 2007:427-428). Karakteristik pribadi seringkali dideskripsikan dalam hal ciri-ciri yang ditunjukkan seseorang yang dapat diukur. Ciri adalah komponen spesifik dari kepribadian yang mendeskripsikan kecenderungan seseorang untuk merasa, berpikir, dan bertindak dengan cara tertentu (Robbins \& Coulter, 2007:427-428). Model Lima Besar dari kepribadian menempatkan lima ciri kepribadian yang umum. Setiap komponen Lima Besar terdiri dari berbagai ciri yang khusus. Faktor kepribadian Lima Besar menggambarkan stabilitas emosi, menyenangkan, percaya diri, hati-hati, and terbuka (Slocum \& Hellriegel, 2009:44-46). Stabilitas emosi menunjukkan kemampuan seseorang untuk melawan tekanan. Sifat menyenangkan adalah sejauh mana seseorang dapat bekerja sama dengan orang lain. Sifat percaya diri adalah sejauh mana seseorang dapat berteman dengan orang lain. Sikap hati-hati berhubungan dengan disiplin diri, bertindak dengan tanggung jawab, dan perilaku terarah. Sifat terbuka mendeskripsikan adanya imajinasi dan kreativitas.

Serupa dengan definisi sebelumnya, ciri kepribadian seseorang dapat mengalami perubahan (Slocum \& Hellriegel, 2009:46). Kepribadian seseorang dapat berkembang pada saat seseorang mendapatkan pengalaman dan situasi yang baru. Penelitian mengenai Lima Besar menemukan adanya hubungan antara dimensi kepribadian dan kinerja kerja (Robbins \& Judge, 2007: 143-145). Lima ciri ini memiliki implikasi terhadap pekerjaan dan kehidupan. Individu yang dapat diandalkan, dipercaya, hati-hati, teliti, dapat merencanakan, teratur, pekerja keras, gigih, dan berorientasi pada pencapaian cenderung memiliki kinerja kerja yang lebih baik untuk sebagian besar pekerjaan. Orang-orang dengan stabilitas emosi yang lebih tinggi lebih bahagia dibandingkan dengan orang-orang dengan stabilitas emosi yang lebih rendah. Orang yang bersifat percaya diri cenderung lebih bahagia dalam pekerjaan dan dalam kehidupan secara keseluruhan. Individu yang bersifat terbuka akan lebih kreatif di bidang ilmu pengetahuan dan seni dibandingkan individu yang bersifat kurang terbuka. Orangorang yang menyenangkan sedikit lebih bergembira dibandingkan dengan orang-orang yang kurang menyenangkan.

Berdasarkan uraian diatas, dapat disimpulkan bahwa karakteristik pribadi pegawai adalah kombinasi unik dari pola emosi, pikiran, dan perilaku yang mempengaruhi bagaimana pegawai bereaksi dan berinteraksi dengan orang lain.

\section{Sifat Pekerjaan}

Dikembangkan oleh J. Richard Hackman dan Greg Oldham, sifat pekerjaan adalah kualitas atau ciri-ciri khusus yang merupakan bagian paling penting atau bagian paling 
sentral dari suatu pekerjaan (Schermerhorn \& Osborn, 2005:146-149). Menurut definisi ini, sifat pekerjaan meliputi lima ciri khusus yang paling sentral. Mereka berusaha mengidentifikasi dengan tepat ciri-ciri khusus yang paling sentral dari suatu pekerjaan yang berkontribusi terhadap pekerjaan yang memotivasi secara intrinsik dan konsekuensi apa dari ciri-ciri khusus ini. Model ciri-ciri khusus pekerjaan ini memfokuskan pada apa yang membuat pekerjaan memotivasi secara intrinsik (Schermerhorn \& Osborn, 2005:146-149). Pada saat pegawai termotivasi secara intrinsik, Hackman and Oldham menyatakan bahwa kinerja yang baik membuat pegawai merasa puas. Perasaan ini memotivasi mereka untuk melanjutkan berkinerja pada level yang tinggi sehingga kinerja yang baik menjadi penguat sendiri. Makin tinggi ciri-ciri khusus suatu pekerjaan, maka makin dapat memperkaya sifat pekerjaan.

Sependapat dengan definisi sebelumnya, variasi keterampilan, identitas pekerjaan, dan signifikansi pekerjaan mempengaruhi seberapa besar pekerjaan dipahami bermakna (Cummings \& Worley, 2005:334). Variasi keterampilan menunjuk pada jumlah dan tipe keterampilan yang digunakan untuk melaksanakan pekerjaan tertentu. Makin banyak pekerjaan yang dilakukan individu, pekerjaan menjadi makin bermakna. Identitas pekerjaan mendeskripsikan seberapa besar individu melaksanakan keseluruhan bagian pekerjaan. Perluasan pekerjaan yang merupakan bentuk lain dari pengayaan pekerjaan yang mengkombinasikan peningkatan variasi keterampilan dengan identitas pekerjaan, mencampurkan beberapa pekerjaan sempit menjadi satu pekerjaan yang lebih besar, dalam arti diperluas. Autonomi menunjuk pada jumlah independensi, kebebasan, dan kebebasan pengambilan keputusan bagi pegawai untuk menjadwalkan dan melaksanakan pekerjaannya. Pegawai akan lebih merasa bertanggung jawab terhadap hasil kerjanya jika terdapat autonomi dalam jumlah besar. Serupa dengan pendapat di atas, ciri-ciri khusus yang paling penting dari suatu pekerjaan menciptakan tiga keadaan psikologi kritis pada pelaksana pekerjaan (Ivancevich, 2007:172). Keadaan psikologi kunci yang diperlukan untuk motivasi dan kepuasan adalah: (1) mengalami kebermaknaan, yaitu tingkatan dimana pelaksana pekerjaan menganggap pekerjaan yang dilakukannya penting; (2) mengalami tanggung jawab, yaitu seberapa besar pelaksana pekerjaan merasa bertanggung jawab secara personal terhadap hasil pekerjaan yang telah dilakukannya; dan (3) pengetahuan dari hasil, yaitu pemahaman bahwa pelaksana pekerjaan menerima seberapa efektif ia telah melakukan pekerjaannya. Berdasarkan penjelasan sebelumnya, dapat disimpulkan bahwa sifat pekerjaan adalah kualitas atau ciri-ciri khusus yang merupakan bagian yang paling penting atau bagian paling sentral dari suatu pekerjaan.

\section{METODE}

Penelitian dilaksanakan di Dinas Pendidikan di Provinsi DKI Jakarta. Tempat penelitian dipilih berdasarkan pentingnya kinerja organisasi di Dinas Pendidikan di Provinsi DKI Jakarta sebagai organisasi yang harus memberikan pelayanan terbaik terhadap sistem pendidikan di Indonesia. Penelitian ini dilaksanakan selama 4 bulan yang dimulai dari Bulan Mei 2009 sampai dengan Bulan September 2009. Sampel sebanyak 150 pegawai.

\section{HASIL DAN PEMBAHASAN}

Pengaruh positif langsung perilaku pemimpin $\left(X_{1}\right)$ terhadap karakteristik pribadi pegawai $\left(X_{2}\right)$ 
Ditunjukkan bahwa nilai koefisien jalur antara perilaku pemimpin dan karakteristik pribadi pegawai $\left(\rho_{21}\right)$ adalah sebesar $0,711(12,3>2,60)$ atau lebih dari 0,05. Oleh karena itu, dapat disimpulkan bahwa perilaku pemimpin memiliki pengaruh positif langsung terhadap karakteristik pribadi pegawai. Kesimpulan ini sesuai dengan teori. Melalui penggunaan salah satu dari keempat perilaku pemimpin, pemimpin berusaha mempengaruhi karakteristik pribadi pegawai. Hal ini berarti bahwa pegawai akan melihat perilaku pemimpin sebagai suatu pengaruh yang memotivasi sampai sejauh mana dianggap sebagai arahan, petunjuk, pelatihan, dan dukungan yang diperlukan dapat diberikan. Dengan kata lain, peningkatan perilaku pemimpin akan mengakibatkan peningkatan karakteristik pribadi pegawai.

\section{Pengaruh positif langsung perilaku pemimpin $\left(X_{1}\right)$ terhadap sifat pekerjaan $\left(X_{3}\right)$}

Ditunjukkan bahwa nilai koefisien jalur antara perilaku pemimpin dan sifat pekerjaan $\left(\rho_{31}\right)$ adalah $0,687(11,5>2,60)$ atau lebih dari 0,05 . Oleh karena itu, dapat disimpulkan bahwa perilaku pemimpin memiliki pengaruh positif langsung terhadap sifat pekerjaan. Kesimpulan ini sesuai dengan teori. Perilaku pemimpin akan menentukan efektivitas sifat pekerjaan. Seorang pemimpin mencoba untuk mendesain pekerjaan untuk memotivasi pegawai untuk melakukan pekerjaan dengan baik, menikmati pekerjaannya, dan menerima hasil yang pantas diterima pegawai. Pemimpin memfokuskan pada apa yang membuat pekerjaan dapat memotivasi secara intrinsik. Pada saat pegawai termotivasi secara intrinsik, kinerja yang baik akan membuat mereka merasa baik. Perasaan ini memotivasi pegawai untuk melaksanakan pekerjaan dengan sangat baik sehingga kinerja yang baik akan terjadi dengan sendirinya. Makin tinggi ciri-ciri khusus suatu pekerjaan, maka pekerjaan makin dianggap diperkaya. Setiap pekerjaan memiliki lima dimensi ciri-ciri khusus yang mempengaruhi motivasi intrinsik, yaitu variasi keterampilan, identitas pekerjaan, signifikansi pekerjaan, autonomi, dan umpan balik. Makin tinggi ciri-ciri khusus suatu pekerjaan pada setiap dimensi, mengakibatkan makin tinggi tingkat motivasi intrinsik. Dengan kata lain, peningkatan perilaku pemimpin akan mengakibatkan peningkatan sifat pekerjaan.

\section{Pengaruh langsung perilaku pemimpin $\left(X_{1}\right)$ terhadap motivasi pegawai $\left(X_{4}\right)$}

Ditunjukkan bahwa nilai koefisien jalur antara perilaku pemimpin dan motivasi pegawai $\left(\rho_{41}\right)$ adalah $0,258(2,92>2,60)$ atau lebih dari 0,05 . Oleh karena itu, dapat disimpulkan bahwa perilaku pemimpin memiliki pengaruh positif langsung terhadap motivasi pegawai. Kesimpulan ini sesuai dengan teori. Perilaku pemimpin efektif sejauh mana pegawai memahami perilaku tersebut sebagai sumber kepuasan langsung atau sebagai instrumental terhadap kepuasan di masa yang akan datang. Perilaku pemimpin bersifat motivasional sampai sejauh mana dapat memuaskan kebutuhan

pegawai yang tergantung pada kinerja efektif dan dapat melengkapi lingkungan pegawai dengan memberikan petunjuk, kejelasan arah, dan penghargaan yang diperlukan untuk kinerja yang efektif. Selain itu, pemimpin sebaiknya memberikan petunjuk dan bimbingan untuk mengklarifikasi perilaku dimana penghargaan ini dapat diperoleh. Hal ini berarti bahwa pemimpin sebaiknya membantu pegawai mengklarifikasikan ekspektansi realistis dan mengurangi hambatan untuk menyelesaikan tujuan yang bernilai. Perilaku terbaik yang sesuai untuk menyelesaikan hal ini diseleksi dan diaplikasikan. Hal ini membutuhkan fleksibilitas dari pemimpin untuk menggunakan perilaku mana yang tepat dalam situasi khusus. Perilaku pemimpin bersifat motivasional sampai sejauh mana dapat membantu pegawai 
menangani ketidakpastian lingkungan. Seorang pemimpin yang mengurangi ketidakpastian pekerjaan dianggap sebagai motivator karena ia meningkatkan ekspektasi pegawai bahwa usahanya akan mengarahkan kepada penghargaan yang diinginkan. Dengan kata lain, peningkatan perilaku pemimpin akan mengakibatkan peningkatan motivasi pegawai.

\section{Pengaruh positif langsung karakteristik pribadi pegawai $\left(X_{2}\right)$ terhadap motivasi pegawai $\left(X_{4}\right)$}

Ditunjukkan bahwa nilai koefisien jalur antara karakteristik pribadi pegawai dan motivasi pegawai $\left(\rho_{42}\right)$ adalah $0,269(3,54>2,60)$ atau lebih dari 0,05. Oleh karena itu, dapat disimpulkan bahwa karakteristik pribadi pegawai memiliki pengaruh positif langsung terhadap motivasi pegawai. Kesimpulan ini sesuai dengan teori. Karakteristik pribadi pegawai adalah sumber potensial dari motivasinya. Model kepribadian Lima Besar menempatkan lima ciri kepribadian umum yang terdiri dari berbagai ciri spesifik yang menggambarkan sifat stabilitas emosi, menyenangkan, percaya diri, hati-hati, dan terbuka dari individu. Orang-orang yang memiliki stabilitas emosi cenderung untuk mengeluarkan lebih banyak ide kreatif dibandingkan individu yang tidak memiliki stabilitas emosi. Pegawai yang menyenangkan adalah seseorang yang memiliki kemampuan untuk bekerja sama dengan orang lain. Pegawai dengan dimensi percaya diri akan menikmati jika bersama dengan orang lain, penuh energi, sering mengalami emosi positif, dan terbuka untuk menetapkan hubungan interpersonal yang baru. Pegawai dengan dimensi hati-hati memiliki sifat bertanggung jawab, teratur, dapat diandalkan, gigih, teliti, dan memiliki disiplin diri karena mereka berkonsentrasi dalam melakukan pekerjaannya dengan baik. Pegawai dengan dimensi terbuka bersifat original, terbuka terhadap berbagai stimuli, memiliki minat yang luas, ingin mengambil resiko, kreatif, selalu ingin tahu, ingin mendengarkan ide-ide baru, memiliki imajinasi yang jelas, menghargai seni dan kecantikan, lebih menyukai variasi daripada rutinitas, dan dapat merubah ide, keyakinan, dan asumsinya sebagai respon terhadap informasi yang baru. Karakteristik pribadi pegawai ini juga sangat berhubungan dengan tingkat motivasinya. Dengan kata lain, peningkatan karakteristik pribadi pegawai akan mengakibatkan peningkatan motivasi pegawai

\section{Pengaruh positif langsung sifat pekerjaan $\left(X_{3}\right)$ terhadap motivasi pegawai $\left(X_{4}\right)$}

Ditunjukkan bahwa nilai koefisien jalur antara sifat pekerjaan dan motivasi pegawai $\left(\rho_{43}\right)$ adalah $0,351(4,77>2,60)$ atau lebih dari 0,05. Oleh karena itu, dapat disimpulkan bahwa sifat pekerjaan memiliki pengaruh positif langsung terhadap motivasi pegawai.

Kesimpulan ini sesuai dengan teori. Sifat pekerjaan akan mempengaruhi motivasi pegawai. Karakteristik pekerjaan berkontribusi untuk memotivasi pekerjaan secara intrinsik. Setiap pekerjaan memiliki lima dimensi ciri-ciri khusus paling sentral yang mempengaruhi motivasi intrinsik, yaitu: variasi keterampilan, identitas pekerjaan, signifikansi pekerjaan, autonomi, dan umpan balik. Makin tinggi ciri-ciri khusus paling sentral dari suatu pekerjaan pada setiap dimensi, mengakibatkan makin tinggi tingkat motivasi intrinsik. Pegawai lebih termotivasi secara intrinsik terhadap pekerjaan yang memiliki variasi keterampilan yang tinggi. Makin tinggi tingkat identitas pekerjaan, makin besar pegawai termotivasi secara intrinsik. Makin tinggi tingkat signifikansi pekerjaan, maka pegawai makin termotivasi secara intrinsik. Secara umum, autonomi yang tinggi berkontribusi terhadap tingkat motivasi intrinsik yang tinggi. Umpan balik memberikan seseorang informasi mengenai kuantitas dan kualitas pekerjaan dan dapat 
bersifat motivasional. Dengan kata lain, peningkatan sifat pekerjaan akan mengakibatkan peningkatan motivasi pegawai.

Pengaruh positif tidak langsung perilaku pemimpin $\left(X_{1}\right)$ terhadap motivasi pegawai $\left(\mathrm{X}_{4}\right)$ melalui karakteristik pribadi pegawai $\left(\mathrm{X}_{2}\right)$

Ditunjukkan bahwa nilai koefisien jalur antara perilaku pemimpin dan motivasi pegawai melalui karakteristik pribadi pegawai adalah 0,1912 atau lebih dari 0,05. Oleh karena itu, dapat disimpulkan bahwa perilaku pemimpin memiliki pengaruh positif tidak langsung terhadap motivasi pegawai melalui karakteristik pribadi pegawai.

Kesimpulan ini sesuai dengan teori. Perilaku pemimpin akan mempengaruhi karakteristik pribadi pegawai. Hal ini akan menentukan motivasi pegawai. Dengan menggunakan salah satu dari keempat jenis perilaku pemimpin, pemimpin berusaha mempengaruhi karakteristik pribadi pegawai. Hal ini berarti bahwa pegawai akan melihat perilaku pemimpin sebagai pengaruh yang memotivasi sejauh mana arahan, petunjuk, pelatihan, dan dukungan yang diperlukan disediakan. Dengan menggunakan salah satu dari keempat jenis perilaku pemimpin, pemimpin berusaha mempengaruhi karakteristik pribadi pegawai. Perilaku pemimpin bersifat efektif sejauh mana pegawai menganggap perilaku itu sebagai sumber kepuasan langsung atau sebagai instrumental terhadap kepuasan di masa yang akan datang. Perilaku pemimpin bersifat motivasional sejauh mana dapat memuaskan kebutuhan pegawai yang tergantung apda kinerja efektif dan dapat melengkapi lingkungan pegawai dengan cara memberikan petunjuk, kejelasan arah, dan penghargaan yang diperlukan untuk kinerja efektif. Perilaku pemimpin bersifat motivasional sejauh mana dapat membantu pegawai mengatasi ketidakpastian lingkungan. Dengan kata lain, peningkatan perilaku pemimpin akan mengakibatkan peningkatan motivasi pegawai melalui peningkatan karakteristik pribadi pegawai.

Pengaruh positif tidak langsung perilaku pemimpin $\left(X_{1}\right)$ terhadap motivasi pegawai $\left(X_{4}\right)$ melalui sifat pekerjaan $\left(X_{3}\right)$

Ditunjukkan bahwa nilai koefisien jalur antara perilaku pemimpin dan motivasi pegawai melalui sifat pekerjaan adalah sebesar 0,2411 atau lebih dari 0,05. Oleh karena itu, dapat disimpulkan bahwa perilaku pemimpin memiliki pengaruh positif tidak langsung terhadap motivasi pegawai melalui sifat pekerjaan. Kesimpulan ini sesuai dengan teori. Perilaku pemimpin akan mempengaruhi sifat pekerjaan. Hal ini akan menentukan motivasi pegawai. Dengan cara menggunakan salah satu dari keempat jenis perilaku pemimpin, pemimpin berusaha mempengaruhi sifat pekerjaan. Perilaku pemimpin ini akan menentukan sifat pekerjaan sehubungan dengan seberapa besar pekerjaan itu bersifat rutin dan terstruktur, atau bersifat tidak rutin dan tidak terstruktur. Seorang pemimpin mencoba mendesain pekerjaan untuk memotivasi pegawai untuk melaksanakan pekerjaan dengan baik, menikmati pekerjaannya, dan menerima hasil yang pantas diterimanya. Pemimpin memfokuskan pada apa yang membuat pekerjaan memotivasi secara intrinsik. Pada saat pegawai termotivasi secara intrinsik, kinerja yang baik akan membuat mereka merasa baik. Perasaan ini memotivasi mereka untuk melanjutkan berkinerja pada level yang tinggi sehingga kinerja yang baik akan menjadi penguat sendiri. Makin tinggi ciri-ciri khusus paling sentral dari suatu pekerjaan, maka suatu pekerjaan makin dianggap diperkaya. Setiap pekerjaan memiliki lima dimensi ciri-ciri khusus paling sentral yang mempengaruhi motivasi intrinsik, yaitu: variasi keterampilan, identitas pekerjaan, signifikansi pekerjaan, autonomi, dan umpan balik. Makin tinggi inti pekerjaan pada setiap dimensi, 
maka motivasi pegawai akan makin tinggi. Dengan kata lain, peningkatan perilaku pemimpin akan mengakibatkan peningkatan motivasi pegawai melalui peningkatan sifat pekerjaan.

\section{PENUTUP}

Kesimpulan. Perilaku pemimpin memiliki pengaruh positif langsung terhadap karakteristik pribadi pegawai artinya peningkatan perilaku pemimpin akan mengakibatkan peningkatan karakteristik pribadi pegawai. Perilaku pemimpin memiliki pengaruh positif langsung terhadap sifat pekerjaan artinya peningkatan perilaku pemimpin akan mengakibatkan peningkatan sifat pekerjaan. Perilaku pemimpin ini akan menentukan sifat pekerjaan sehubungan dengan ciri-ciri khusus paling sentral dari suatu pekerjaan. Perilaku pemimpin memiliki pengaruh positif langsung terhadap motivasi pegawai artinya peningkatan perilaku pemimpin akan mengakibatkan peningkatan motivasi pegawai. Karakteristik pribadi pegawai memiliki pengaruh positif langsung terhadap motivasi pegawai artinya peningkatan karakteristik pribadi pegawai akan mengakibatkan peningkatan motivasi pegawai. Sifat pekerjaan memiliki pengaruh positif langsung terhadap motivasi pegawai artinya peningkatan sifat pekerjaan akan mengakibatkan peningkatan motivasi pegawai. Perilaku pemimpin memiliki pengaruh positif tidak langsung terhadap motivasi pegawai melalui karakteristik pribadi pegawai artinya peningkatan perilaku pemimpin akan mengakibatkan peningkatan motivasi pegawai melalui peningkatan karakteristik pribadi pegawai. Perilaku pemimpin memiliki pengaruh positif tidak langsung terhadap motivasi pegawai melalui sifat pekerjaan artinya peningkatan perilaku pemimpin akan mengakibatkan peningkatan motivasi pegawai melalui peningkatan sifat pekerjaan.

Saran. Kepala Dinas Pendidikan provinsi DKI Jakarta sebaiknya sangat memperhatikan sifat pekerjaan yang diberikan kepada pegawai karena secara positif berkorelasi dengan motivasi pegawai. Selain itu, program yang lebih baik dalam pendidikan dan pelatihan sebaiknya diberikan untuk meningkatkan motivasi pegawai. Kepala Dinas Pendidikan Provinsi DKI Jakarta sebaiknya membuat kebijakan yang tepat untuk meningkatkan motivasi pegawai sebagai suatu usaha untuk perbaikan yang berkelanjutan. Penelitian sumber daya mansia sebaiknya menggunakan hasil penelitian untuk menganalisa lebih dalam terutama untuk faktor lain yang mempengaruhi motivasi pegawai.

\section{DAFTAR RUJUKAN}


Colquitt, Jason et.al. Organizational Behavior. New York: McGraw-Hill. 2009.

Cummings, Thomas G \& Worley, Christopher G. Organization Development and Change. Eighth Edition. USA: Thomson. 2005.

DuBrin, Andrew J. Fundamentals of Organizational Behavior. Fifth Edition. USA: Thomson. 2002.

Engler, Barbara. Personality Theories. Eighth Edition. USA: Houghton Mifflin Harcourt. 2009.

George, Jennifer M \& Jones, Gareth R. Understanding and Managing and Organizational Behavior. Fourth Edition. New Jersey: Prentice Hall. 2005.

Gibson, James L et.al, Organizations. Twelfth Edition. Singapore: McGraw Hill. 2006.

Gomez-Mejia, Luis R \& Balkin, David B. Management. New York: McGraw-Hill. 2002.

Hitt, Michael A. et.al. Management. Second Edition. New Jersey: Prentice Hall. 2009

Ivancevich, John M. Human Resource Management. Tenth Edition. Singapore: McGrawHill. 2007.

Mullins, Laurie J. Management and Organizational Behavior. Seventh Edition. England: Prentice Hall. 2005.

Nelson, Debra L \& Quick, James Campbell. Organizational Behavior. Fifth Edition. USA: Thomson. 2006.

Newstrom, John W. Organizational Behavior. Twelfth Edition. Singapore: McGraw-Hill. 2007.

Robbins, Stephen P \& Judge, Timothy A. Organizational Behavior. 13th Edition. New Jersey: Pearson Prentice Hall. 2009

Robbins, Stephen P \& Judge, Timothy A. Organizational Behavior. Twelfth Edition. New Jersey: Pearson Prentice Hall. 2007.

Robbins, Stephen P. \& Coulter, Mary. Management. Ninth Edition. New Jersey: Prentice Hall. 2007. 